\title{
Westinghouse Hanford Company Nol: 019.91 Waste Minimization and Pollution Prevention Awareness Program Plan
}

Prepared for the U.S. Department of Energy Office of Environmental Restoration and Waste Management

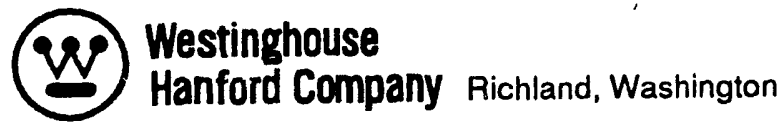

Hanford Operations and Engineering Contractor for the

U.S. Department of Energy under Contract DE-AC06-87RL10930

Approved for Public Release 


\section{LEGAL DISCLAIMER}

This report was prepared as an account of work sponsored by an agency of the United States Government. Neither the United States Government nor any agency thereof, nor of their employees, nor any of their contractors, subconti, th.s or their employees, makes any warranty, express or implied, or assumes any legal liability or responsibility for the accuracy, completeness, or any third party's use or the results of such use of any information, apparatus, product, or process disclosed, or represents that its use would not infringe privately owned rights. Reference herein to any specific commercial product, process, or service by trade name, trademark, manufacturer, or otherwise, does not necessarily constitute or imply its endorsement, recommendation, or favoring by the United States Government or any agency thereof or its contractors or subcontractors. The views and opinions of authors expressed herein do not necessarily state or reflect those of the United States Government or any agency thereof.

This report has been reproduced from the best available copy. Available in paper copy and microfiche.

Available to the U.S. Department of Energy and its contractors from

Olfice of Scientific and Technical Information

P.O. Box 62

Oak Ridge, TN 37831

(615) $576-8401$

Available to the public from the U.S. Department of Commerce National Technical Information Service

5285 Port Royal Road

Springfiold, VA 22161

(703) $487-4650$

Printed in the United States of America

DISCLM-1.CHP (1.91) 


\title{
Westinghouse Hanford Company \\ Waste Minimization and Pollution Prevention Awareness Program Plan
}

\author{
P. A. Craig \\ D. H. Nichols \\ D. W. Lindsey
}

Date Published

August 1991

Prepared for the U.S. Department of Energy

Office of Environmental Restoration and

Waste Management

Westinghouse
Hantord Company Richland, Washington 99352
Hanford Operations and Engineering Contractor for the
U.S. Department of Energy under Contract DE-ACO6-87RL 10930

Approved for Public Release 


\section{CONTENTS}

GLOSSARY

I. INTRODUCTION/BACKGROUND . . . . . . . . . . . . . . 1

A. PURPOSE OF PLAN . . . . . . . . . . . . . . . . . . . 1

B. SCOPE OF PLAN $\dot{1}$.

II. RESOURCES ...................... . 5

III. POLICY . . . . . . . . . . . . . . . . . . . 6

IV. STRATEGY, OBJECTIVES, AND GOALS . . . . . . . . . . . . . . . . 7

A. STRATEGY . . . . . . . . . . . . . . . . . 7

B. PROGRAM OBJECTIVES ................... . . . 7

C. GOALS .................... . . 9

D. SCHEDULE OF ACTIVITIES . . . . . . . . . . . . . . . . . . . . . 9

V. ORGANIZATION AND STAFF RESPONSIBILITIES . . . . . . . . . . 10

VI. COST ACCOUNTING . . . . . . . . . . . . . . . . . 10

VII. PROCESS WASTE ASSESSMENTS . . . . . . . . . . . . . . 12

VIII. WASTE MINIMIZATION TECHNIQUES . . . . . . . . . . . . . . . . 13

A. INVENTORY MANAGEMENT . . . . . . . . . . . . . . . . . . . . 13

B. OPERATIONAL CHANGES .................. 13

C. MAINTENANCE PROGRAM .................... 14

D. MATERIAL CHANGE . . . . . . . . . . . . . . . . . 14

E. PROCESS EQUIPMENT MODIFICATION . . . . . . . . . . . . . . . 14

F. RECYCLING AND REUSE . . . . . . . . . . . . . . 14

IX. TRAINING, AWARENESS, INCENTIVES . . . . . . . . . . . . 15

A. POLLUTION PREVENTION AWARENESS . . . . . . . . . . . . . 15

B. POLLUTION PREVENTION AWARENESS CAMPAIGN . . . . . . . . . . . 16

C. AWARDS AND RECOGNITION ................... . 16

D. INFORMATION EXCHANGE ................... 16

E. TRAINING ........................ 16

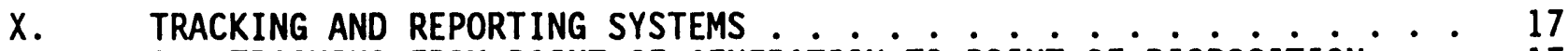

A. TRACKING FROM POINT OF GENERATION TO POINT OF DISPOSITION • . 17

B. PROCUREMENT CONTROL SYSTEM . . . . . . . . . . . . . 17

C. PROGRAM ACTIVITY TRACKING ................. . . 17

D. FEDERAL AND STATE REPORTING REQUIREMENTS . . . . . . . . . . . 18

XI. QUALITY ASSURANCE . . . . . . . . . . . . . . . 18

XII. INFORMATION EXCHANGE AND OUTREACH ............... 18 


\section{CONTENTS (continued)}

XIII. TECHNOLOGY TRANSFER ..................... 18

XIV. RESEARCH AND DEVELOPMENT . . . . . . . . . . . . . . . . 19

XV. PROGRAM EVALUATION ..................... 19

XVI. REFERENCES . . . . . . . . . . . . . . . . . 20

APPENDIXES:

A WASTE MINIRIZATION GOALS . . . . . . . . . . . . . . APP A-1

B DETAILED SCHEDULE FOR WASTE MINIMIZATION PROGRAM ACTIVITIES . . . APP B-1

\section{FIGURES}

1 Waste Reduction Techniques. ................... 3

2 Waste Minimization Program Organizational Chart . . . . . . . . . 11

TABLE

1 Waste Minimization Plan Outline ............... 8 
WHC-EP-0496

\section{GLOSSARY}

\section{DEFINITIONS OF TERMS}

Recycling. Recycling techniques are characterized as use, reuse, and reclamation techniques (resource recovery). Use or reuse involve the return of a potential waste material either to the originating process as a substitute for an input material or to another process as an input material. Reclamation is the recovery of a useful or valuable material from a waste stream. Recycling allows potential waste materials to be put to a beneficial use instead of going to treatment, storage, or disposal.

Source Reduction. The elimination or reduction of waste generation at the source. Source reduction activities and techniques include substitution of less hazardous materials, process optimization or modification, technology changes and administrative changes sush as inventory control, and housekeeping practices such as waste segregation. Source reduction results in reducing or eliminating the amount of potential waste material exiting from a process.

Treatment. Technological processes that reduce the volume, toxicity, or mobility of waste after it has been created. Examples include, but are not limited to, incineration, vitrification, neutralization, chemical extraction, physical separation, and solidification/stabilization technologies.

Waste Minimization. Elimination or minimization of the generation of waste before treatment, storage, or dispos 11 . Waste minimization is any source reduction or recycling activity that results in (1) reduction of total volume of waste, (2) reduction of toxicicy of waste, or (3) both (1) and (2), as long as that reduction is consistent with the general goal of minimizing present and future threats to human health and the environment.

Waste Reduction. Reduction of the total amount of waste that is generated and disposed of by U.S. Department of Energy operations through waste minimization and treatment activities.

Pollution Prevention. The elimination or minimization of waste across all media using source reduction techniques. This term coiers activities such as energy conservation and the activities defined as source reduction. 
WHC-EP-0496

\section{WESTINGHOUSE HANFORD CONPANY \\ WASTE MINIMIZATION AND POLLUTION \\ PREVENTION AWARENESS \\ PROGRAN PLAN}

\section{INTRODUCTION/BACKGROUND}

\section{A. PURPOSE OF PLAN}

The purpose of this plan is to establish the Westinghouse Hanford Company's Waste Minimization Program. The plan specifies activities and methods that will be employed to reduce the quantity and toxicity of waste generated at Westinghouse Hanford Company (Westinghouse Hanford). It is designed to satisfy the U.S. Department of Energy (DOE) and other legal requirements that are discussed in Subsection $C$ of this section. The Pollution Prevention Awareness Program is included with the Waste Minimization Program as permitted by DOE Order 5400.1 (DOE 1988a). This plan is based on the Hanford Site Waste Minimization and Pollution Prevention Awareness Program Plan, which directs DOE Field Office, Richland contractors to develop and maintain a waste minimization program.

\section{B. SCOPE OF PLAN}

A waste minimization program is an organized, comprehensive, and continual effort to systematically reduce waste generation. The Westinghouse Hanford Waste Minimization Program is designed to prevent or minimize pollutant releases to all environmental media from all aspects of Westinghouse Hanford operations and offers increased protection of public health and the environment. These efforts also yield the following additional benefits:

- Reduction of waste management and compliance costs

- Reduction of resource usage

- Improvement of product yields

- Reduction or elimination of inventories and releases of hazardous chemicals reportable under the "Emergency Planning and Community Right-to-Know Act" (Superfund Amendments and Reauthorization Act of 1986)

- Reduction or elimination of civil and criminal liabilities under environmental laws.

The program reflects the goals and policies for waste minimization of Westinghouse Hanford and represents an ongoing effort to make waste minimization part of Westinghouse Hanford's operating philosophy. In accordance with Environmental Protection Agency (EPA) and DOE policy, a hierarchical approach to waste management has been adopted and is applied to all types of waste. 
A hierarchy of waste management practices places the priority on source reduction, followed by recycling, treatment, storage, and disposal, in that order. The waste minimization program emphasizes the elimination or minimization of waste through source reduction. Potential waste materials that cannot be eliminated or minimized will be evaluated for recycling (i.e., used, reused, or reclaimed). However, the DOE has defined 'waste reduction' as adding treatment to waste minimization to ensure that all waste that is nevertheless generated or previously has been generated will be treated to reduce its volume, toxicity, or mobility before storage or disposal (see Figure 1). This document will focus on the waste minimization program.

This plan is a reference tool and guidance document for managers, operations personnel, and support staff. It contains the policy, objectives, strategy, and support activities of the waste minimization program. Primary elements of the plan are (1) waste minimization goals, (2) the development of waste generation baseline information through waste assessments, and (3) a process for continual evaluation of the program. Various waste minimization techniques will be implemented with the support of employee training and awareness programs to reduce waste and still meet the requirements for quality, productivity, safety, and environmental compliance.

This plan applies to all Westinghouse Hanford facilities. This plan will be reviewed annualiy and revised as necessary. At a minimum, the plan will be updated every 3 yr.

The plan will be distributed to waste minimization program employees and facility minimization representatives, and the policy, goals, objectives, and strategy of the program will be communicated to all Westinghouse Hanford employees.

\section{LEGAL AND POLICY BACKGROUND}

The Resource Conservation and Recovery Act of 1976 (RCRA) requires hazardous waste generators to establish a program to reduce the volume or toxicity of waste to the degree determined by the generator to be "economically practicable." Hazardous waste generators must certify in their waste manifest that this requirement has been fulfilled. Generators also must identify in the EPA-required biennial waste minimization report the efforts undertaken during the year to reduce the volume and toxicity of waste generated and the changes in volume and toxicity actually achieved. The Washington State Department of Ecology (Ecology) has regulatory enforcement for RCRA in Washington. The Washington Administrative Code 173-303 (Ecology 1991a) is used for this purpose. Furthermore, the Washington Administrative Code 173-307, Hazardous Waste Facilities Plans (Ecology 1991) may require a waste minimization plan with detailed process data and minimization evaluations for many DOE Field Office, Richland facilities. The "Pollution Prevention Act of 1990" (Omnibus Reconciliation Act of 1990) requires waste generators to report waste minimization results in their annual submission of toxic chemical release inventories to the EPA starting in June 1992. 
The DOE Orders 5400.1 (DOE 1988a), 5400.3 (DOE 1989), and 5820.2A (DOE 1988b) and DOE Field Office, Richl and policy mandate that the management of hazardous, radioactive, and other wastes shall be accomplished in a manner that minimizes the generation of such wastes.

The DOE Order 5400.1 (DOE 1988a) establishes environmental protection program requirements and responsibilities for ensuring compliance with environmental protection laws. The order requires the establishment of a waste minimization program "that will contain goals for minimizing the volume and toxicity of all wastes that are generated" and a Pollution Prevention Awareness Program. The two programs have been combined in this $p l a n$ as allowed by the order. The order also requires the completion of an annual report summarizing waste reduction efforts.

The DOE Order 5400.3 (DOE 1989) establishes DOE hazardous and radioactive mixed waste policies and requirements, and implements the requirements of RCRA within the framework of the environmental programs established under DOE Order 5400.1 (DOE 1988a). The DOE Order 5400.3 (DOE 1989b) states that it is DOE policy to "implement waste minimization measures as specified in RCRA for hazardous and radioactive mixed wastes." The order also requires the heads of field organizations to "implement a waste minimization program for hazardous and radioactive mixed wastes."

The DOE Order 5820.2A (DOE 1988b) establishes policies, guidelines, and minimum requirements by which DOE manages its radioactive and mixed waste and contaminated facilities. It states the following:

...generation, treatment, storage, transportation, and/or disposal of radioactive wastes, and the other pollutants or hazardous substances they contain, shall be accomplished in a manner that minimizes the generation of such wastes across program office functions and complies with all applicable federal, state, and local environmental, safety, and health laws and regulations and DOE requirements.

The order requires the preparation of a waste management $p l a n$ for each site that generates, treats, stores, or disposes of DOE waste. The elements of the waste management $p l a n$ are incorporated into the Site-specific plan, which "will indicate actions to minimize hazardous waste generation" as specified in the order.

The DOE Order 5820.2A (DOE 1988b) contains specific waste minimization requirements for management of high-level, transuranic, and low-level waste. These requirements include process modification, process optimization, and materials substitution.

The DOE has a waste reduction policy that requires all DOE Program Offices and field Operations to institute a waste reduction colicy to reduce the total amount of waste that is generated and disposed of by DOE operating facilities through waste minimization (source reduction and recycling) and waste treatment. The policy consolidates the requirements of DOE Orders 5400.1, 5400.3, and 5820.2A (DOE 1988a, 1989, and 1'388b, respectively) for either a waste minimization or a waste reduction fla: and attaches guidance for satisfying the reporting requirements nf those orders. The 


\section{WHC-EP-0496}

Figure 1. Waste Reduction Techniques.

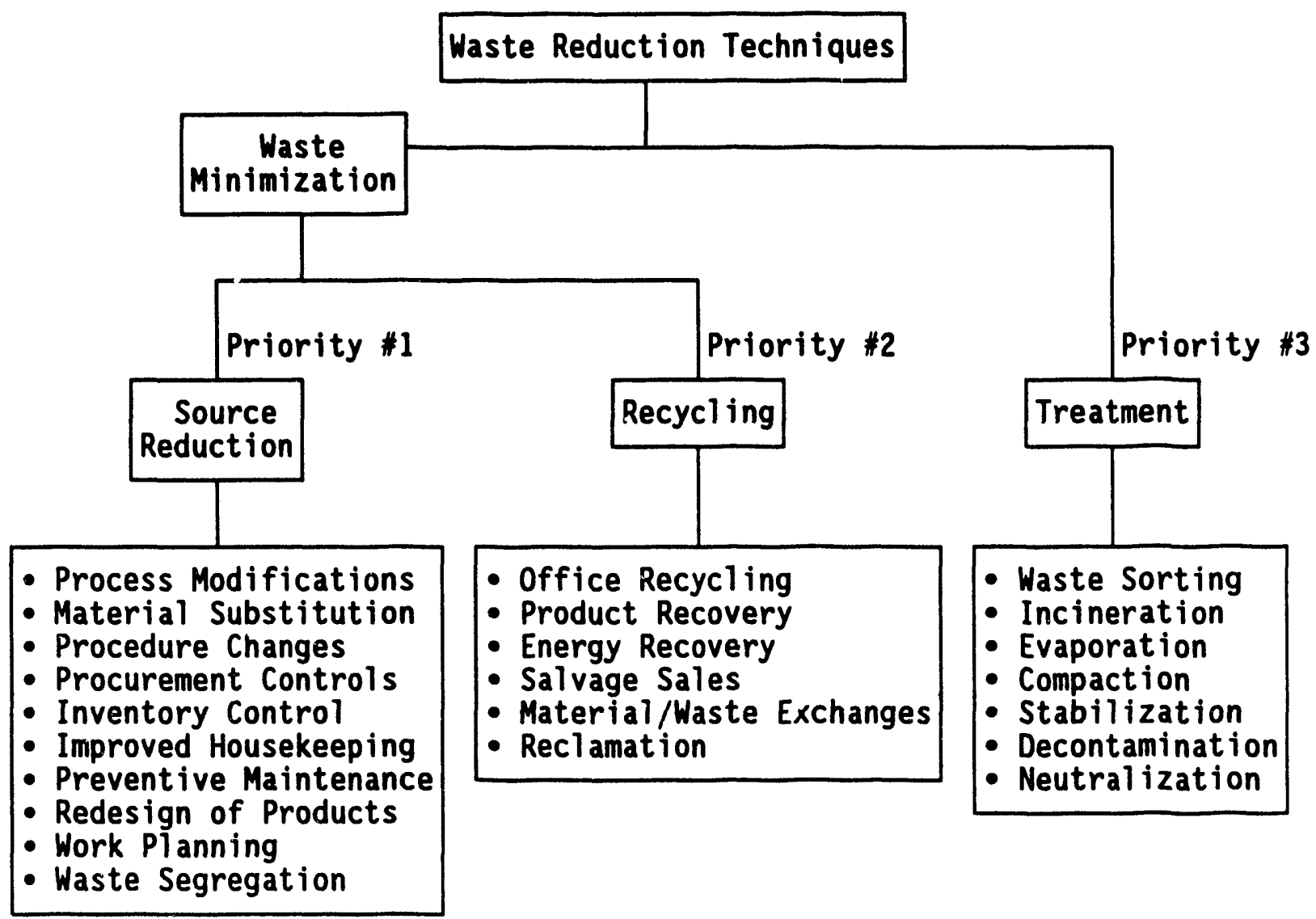


statement adopts the hierarchical approach to waste reduction and applies the policy to all types of waste. The policy requires waste reduction to be a "prime consideration" in research activities, process design, and facility design and operations.

The DOE Policy, "Environmental Protection Policy for Richland Operations," establishes DOE Field Office, Richland's commitment to conduct operations "in compliance with the letter and spirit of applicable environmental statutes, regulations, and standards." It states that it is DOE Field Office, Richland policy to take "appropriate measures to prevent the generation of contaminants, wastes, and other residual materials requiring disposal or release to the environment through source reduction and

recycling." In addition, individual direction letters are issued by DOE Field Office, Richland regarding requirements for the waste minimization program. These letters are filed and maintained by Waste Minimization and Reduction (WM\&R).

\section{RESOURCES}

Funding for waste minimization activities at Westinghouse Hanford is provided by the Hanford Environmental Management Program (ADS 9050 through 9054). The focus of this funding is to coordinate waste minimization programs that encompass all Hanford Site contractors. Activities supported include the following:

- Development of the DOE Field Office, Richland Hanford Site Waste Minimization and Pollution Prevention Program Plan

- Development of the waste minimization chapter for the Hanford Site Part B permit application

- Submittal of the annual "Waste Reduction Report" to DOE Field Office, Richland for the Hanford Site

- Submittal of the "Biennial Waste Minimization Report" to the Environmental Protection Agency/Ecology

- Development of the Hanford Technology Program Plan for Waste Minimization.

Hanford Environmental Management Program funding also supports Westinghouse Hanford program implementation. Each waste generating facility is responsible for funding their own waste minimization activities. Requests have been made for additional funding for waste minimization and recycling programs. 


\section{POLICY}

Management Policy (MP) 5.17, "Waste Minimization" (WHC 1987a), states that "the generation of radioactive, hazardous, and mixed waste at Westinghouse Hanford will be minimized to the maximum extent economically practical and consistent with the safe operation of all facilities." The policy also defines management and employee responsibilities regarding waste minimization.

Management Requirements and Procedures (MRP) 5.44 (WHC 1987b), "Waste Minimization Program," provides a synopsis of program purpose, scope, and regulatory definitions. This procedure defines specific requirements for which Westinghouse Hanford management and other employees are responsible for establishing and applying the principles of a waste minimization program. Requirements include the following:

(1) A waste minimization plan for each waste-generating facility

(2) Implementation and tracking of the facility-specific waste minimization plan

(3) Support for regulatory information requirements

(4) Annual waste minimization goals for each waste-generating facility

(5) Status of waste minimization goals quarterly to the Waste Minimization and Reduction organization

(6) Evaluation of quarterly status reports by the Waste Minimization Team and summary of these goals in an annual report

(7) Waste minimization activities reported to regulatory agencies as required

(8) Employee training on the Westinghouse Hanford Waste Minimization Program and regulatory requirements

(9) Documented certification stating that a waste minimization $p l a n$ is in place must be completed annually and inserted into the facility operating record.

Requirements in MRP 5.44 (WHC 1987b) apply to all current and planned activities at Westinghouse Hanford that generate hazardous, radioactive, and mixed waste. 
WHC-EP-0496

IV. STRATEGY, OBJECTIVES, AND GOALS

\section{A. STRATEGY}

The Westinghouse Hanford waste minimization program exists at two levels: individual facility-specific programs and an overall company program. Each of these is described in more detail in the following paragraphs.

Facility-Specific Plans - The strategy for the Westinghouse Hanford Waste Minimization Program is to encourage waste minimization activities at the level of waste generation. Each Westinghouse Hanford facility that generates, treats, stores, or disposes of hazardous, radioactive, or mixed waste has prepared a facilit,y-specific waste minimization plan. The $p l$ an focuses on a facility's specific waste. Each individual waste stream is identified and characterized with respect to origin, composition, quantity generated, cost, environmental and safety impacts, and waste minimization potential. The plan will provide a vehicle for setting annual waste minimization goals and a trackable system for documenting waste minimization achievements.

The outline for these plans is given in Table 1. This ensures consistent content and format of all facility-specific waste minimization plans.

Sections 1.0, "Introduction," and 2.0, "Waste Minimizatior Frogram," are to be issued by each facility as a document. The appendices are issued as letter reports to make the facility-specific plans a "living document."

Overall Company Programs - There are many activities that can be developed to provide benefits to many individual waste-generating facilities. These activities are coordinated by the Waste Minimization and Reduction organization. Examples of these activities include the surplus chemical exchange database, which was developed to allow the exchange of excess chemicals across the Hanford Site, the paper :ecycling program, and process waste assessments.

\section{B. PROGRAM OBJECTIVES}

The objectives of the Westinghouse Hanford waste minimization program are follows:

- Foster a philosophy to conserve resources, and minimize waste and pollution while achieving Westinghouse Hanford strategic objectives

- Promote the use of nonhazardous materials in activities to minimize the potential risks to human health and the environment

- Reduce or eliminate the generation of waste through input substitution, process modification, improved housekeeping, and closed-loop recycling to achieve minimal adverse effects to the air, water, and 1 and

- Comply with federal and state regulations, and DOE requirements for waste minimization, waste reduction, and pollution prevention 
Table 1. Waste Minimization Plan Outline.

\subsection{INTRODUCTION}

1.1 Purpose/Scope of Pian

1.2 Facility Background

1.2.1 Facility Description

1.2.2 Material Use

1.2.3 Major Categories of Waste Streams

\subsection{WASTE MINIMIZATION PROGRAM}

2.1 Waste Minimization Organization

2.2 Responsibilities

2.3 Training Program

2.4 Employee Participation/Incentive Program

2.5 Waste Minimization for New Projects/Designs

\subsection{APPENDICES}

Appendix A Waste Stream Identification/Minimization Potential

A.1 Origin

A.2 Regulatory Status

A.3 Quantity Generated (Baseline)

A. 4 Costs

A.5 Environmental/Safety Impacts

A.6 Waste Minimization Potential

Appendix B Goals/Progress Reports

B.1 Goals

B.2 Waste Minimization Accomplishments 
- Characterize waste streams and develop a baseline of waste generation data

- Identify and impiement methods and technologies for waste minimization

- Target policies, procedures, or practices that may be barriers to waste minimization

- Inhance communication of waste minimization objectives, goals, and ideas

- Promote integration and coordination of waste generators and waste managers on waste minimization matters

- Develop specific goals and schedules for waste minimization activities

- Create incentives for waste minimization

- Develop and implement employee pollution prevention awareness and occupational training programs

- Collect and exchange waste minimization information through technology transfer, outreach, and educational networks

- Develop mechanisms for fully disseminating current technical information to Site users.

\section{GOALS}

A goal of $50 \%$ reduction in routine waste generated by Westinghouse Hanford facilities has been established by the president of Westinghouse Hanford. Numerical goals for the minimization of specific types of wastes generated at Westinghouse Hanford are provided in Appendix A. These specific goals are based on the DOE Field Office, Richland goals established in the Hanford Site plan and may be adjusted after the performance of comprehensive process waste assessments at generating facilities. Values represent a percent reduction of the baseline value adjusted for changes in production rates, new processes, and Site stabilization and remediation actions.

\section{SCHEDULE OF ACTIVITIES}

A detailed schedule of waste minimization activities is presented in Appendix B. 


\section{ORGANIZATION AND STAFF RESPONSIBILITIES}

Figure 2 depicts the interaction of various Westinghouse Hanford organizations as related to the waste minimization program. The Wast: Minimization and Reduction organization interprets legislative and $\mathrm{DO}_{\text {. }}$ requirements as applied to Westinghouse Hanford. They also assist Westinghouse Hanford facilities in waste minimization efforts, coordinate process waste assessments, and collect data for reporting minimization efforts to DOE and regulatory agencies. In addition, Waste Minimization and Reduction oversees waste minimization activities for the Hanford Site and coordinates the overall comprehensive waste minimization program. This group meets regularly with DOE Field Office, Richland and representatives from the other Hanford Site contractors. The main objective of this group will be to implement the overall Hanford Site Waste Minimization Program (DOE 1991).

The Environmental Awareness Program educates employees on environmental issues including waste minimization. They also interface with the community to communicate Westinghouse Hanford's activities concerning the environment.

A new recycling organization has been established to coordinate paper recycling at Westinghouse Hanford, Kaiser Engineers Hanford, and Hanford Environmental Health Foundation. This organization will expand to the recycling of other materials as funding is made available.

Waste-generating facilities prepare waste minimization plans, conduct process waste assessments to identify waste minimization opportunities, set minimization goals, implement minimization opportunities, and report successes and failures.

\section{vi. COST ACCOUNTING}

A cost accounting system will be developed that accounts for the "true cost" of waste that is generated by the Company and permits meaningful reviews and audits to be conducted. The system shall consider the short- and longterm costs arising from (1) underutilization of raw materials found in the waste stream, (2) management of the waste that is generated, (3) waste disposal, and (4) third-party liabilities if the waste is disposed of improperiy. Associated costs will include personnel, record keeping, transportation (including onsite movement), pollution control equipment, treatment, storage, disposal, liability, compliance, and oversight costs.

The costs derived from the cost accounting system will be included in proposals, planning, and budgeting. To the extent possible, departments and managers will be charged "true" waste management costs for the waste they generate. 
Figure 2. Waste Minimization Program Organizational Chart.

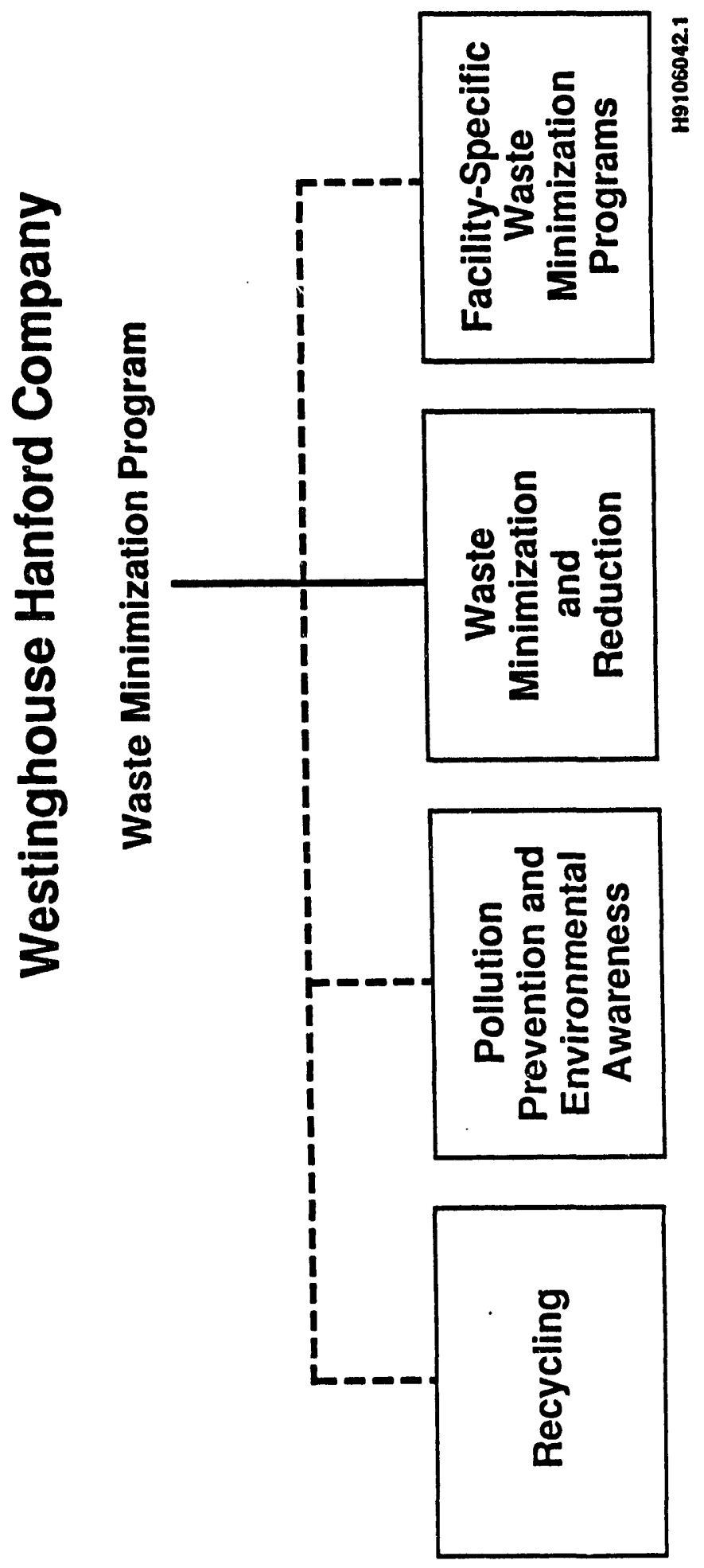




\section{PROCESS WASTE ASSESSMENTS}

Process waste assessments will be conducted as part of an ongoing program to identify, screen, and analyze options to reduce waste generation. A process waste assessment will determine the amount of material in a workplace that is disposed of as waste during work operations. It also will provide a summary of hazardous materials use and waste production, and identify processes and operations that need to be improved or replaced to promote waste minimization. The assessment will provide a basis for setting priorities for the specific modifications to Site processes or other waste minimization options that are developed during the assessment.

Assessments of all waste-generating operations at Westinghouse Hanford will be conducted by a Waste Assessment Team organized and led by the DOE Field Office, Richland Waste Minimization Coordinator. The core team will include the DOE Field Office, Richland Waste Minimization Coordinator and Westinghouse Hanford Waste Minimization and Reduction personnel. The remainder of the assessment team will be drawn from DOE Field Office, Richland and Westinghouse Hanford line, staff, or subcontractor organizations who can furnish the types of specialized expertise that will be needed to conduct the assessment.

The Waste Assessment Team will consist of individuals familiar with the facility, who will steer the assessment efforts and guide data gathering. Personnel used on a part-time basis will provide particular expertise as the need arises. The team will include members who have knowledge in the following areas:

- Federal, state, and local hazardous waste statutes and regulations

- Production and waste minimization principles and techniques

- Quality control requirements

- Purchasing and material control/inventory.

The Waste Assessment Team will determine the order and areas of facilities to be assessed. The Waste Assessment Team will develop process area flow diagrams, material balances, process descriptions, and waste stream characterizations for the assigned assessment area. The DOE guidance, the EPA Waste Minimization Opportunity Assessment Manual, and the EPA Guides to Pollution Prevention-Research and Educational Institutions will be used in conducting the assessments (EPA 1989; EPA 1990).

Completion of the flow diagrams, material balances, and related narratives of waste-generating processes will permit the identification of process inefficiencies that may be modified or corrected to reduce waste generation. These waste minimization opportunities will be evaluated and implemented if economically feasible. The team will report the data and findings from its assessment and recommend options for waste minimization. When identifying waste minimization options, the Waste Assessment Team will concentrate first on source reduction options, followed by recycling technologies. 
The Waste Assessment Team will evaluate waste minimization opportunities and will screen the options using criteria suggested in EPA (1989) to identify those deserving careful evaluation. The screening process will result in a list of options that are candidates for technical and economic evaluation.

The Waste Assessment Team will evaluate the potential technical success and economic cost/benefit of each option resulting from the screening. The options will then be ranked in order of preferred implementation. Projects that reduce waste generation at the source normally will be given the highest priority followed by projects that recycle all or part of a waste stream. The Waste Assessment Team will report the results of its evaluation, including final rankings and ranking criteria.

A schedule for conducting waste assessments and evaluating waste minimization options will be developed. Waste assessments will be conducted on a recurring basis during the life of the waste minimization program.

\section{WASTE MINIMIZATION TECHNIQUES}

Waste minimization encompasses activities that minimize or eliminate the generation of waste and recycling processes that use, reuse, or reclaim a material from a waste stream. Each Westinghouse Hanford facility will employ the following techniques to minimize the generation of waste.

\section{A. INVENTORY MANAGEMENT}

Methods to control the types and quantities of materials in its inventory will be reviewed. Where necessary, inventory control techniques will be revised or expanded to reduce inventory size and hazardous chemical use while increasing inventory turnover. Specifically, inventory control techniques shall be used to reduce waste resulting from excess raw materials that are out of date and no longer used. Similarly, material controls shall be revised or expanded to reduce raw material and finished product loss and damage during handling, production, and storage. The inventory management techniques shall be applied to waste material as well as to raw materials and finished products.

The review of inventory management techniques shall include (1) a study of how existing inventory management procedures can be applied more effectively, (2) whether new techniques should be added to or substituted for current procedures, (3) the need for review and evaluation approval procedures for the purchase of materials, and (4) the need for additional employee training.

\section{B. OPERATIONAL CHANGES}

Processes will be reviewed to determine whether significant reduction of waste at the source can be achieved by improvements in process efficiency. Operating procedures shall be examined to determine whether the elimination or 
revision of operating procedures can contribute to the reduction of waste. The revision and review of operating procedures will be fully documented and incorporated as part of the Westinghouse Hanford employee training program. Techniques such as segregation (i.e., separating hazardous wastes and recoverable wastes from the total waste stream) will be explored.

\section{C. maINTENANCE PROGRAM}

The equipment maintenance program will be reviewed. The review will be used to determine whether improvements in corrective and preventive maintenance can reduce equipment failures that generate waste. The methods for maintenance cost tracking and preventive maintenance scheduling and monitoring will be examined.

Maintenance procedures will be reviewed to determine which are contributing to the production of waste in the form of process materials, scrap, and cleanup residue. The need for revising operational procedures and modifying equipment, and the need for source segregation and recovery will be determined.

\section{MATERIAL CHANGE}

The replacement, reformulation, reduction, or elimination of hazardous materials in production, maintenance, and cleaning processes will be examined.

\section{E. PROCESS EQUIPMENT MODIFICATION}

The effect of waste minimization by the installation of new equipment or the modification of existing equipment will be considered.

\section{F. RECYCLING AND REUSE}

The recovery of wastes will be used as an option in the waste minimization program after reducing the amount of waste generated at the source is first considered. Opportunities for reclamation and reuse of waste materials will be explored whenever feasible. Decontamination of tools, equipment, and materials for reuse or recycle will be used to the extent practicable to minimize the amount of waste for disposal.

Impediments to recycling, whether regulatory or procedural, will be pursued by WM\&R to enable generators to recycle whenever possible. The lack of a "below-regulatory-concern" valve has been recognized as an impediment to the reusing and recycling of materials and waste generated inside radiation zones. 
Some activities commonly thought to be waste minimization are actually waste treatment. The following activities are not considered waste minimization:

- Transferring the constituents of hazardous waste from one environmental medium to another

- Concentration conducted solely for reducing volume

- Dilution as a means of toxicity reduction, unless later recycling steps are involved.

If the activity is performed solely to make the waste more amenable to disposal (e.g., reduce volume or toxicity before storage or disposal) then the waste is being treated, not minimized.

As stated in Section I, Westinghouse Hanford uses a hierarchy of methods placing primary importance on source reduction efforts to eliminate or reduce the creation of waste. Potential waste that cannot be eliminated or minimized $w^{*} 11$ be evaluated for recycle (i.e., used, reused, or reclaimed). A11 waste that is nevertheless generated or has been previously generated will be treated to reduce its volume, toxicity, or mobility before storage or disposal.

\section{TRAINING, AWARENESS, INCENTIVES}

\section{A. POLLUTION PREVENTION AMARENESS}

A successful waste minimization program requires employee commitment. By educating employees in the principles and the rewards of waste minimization, solutions to current and potential waste management problems can be found. Waste minimization awareness has been incorporated into the Environmental Awareness Program (EAP), which is geared toward educating all Westinghouse Hanford employees in all aspects of the environmental activities occurring at the Hanford Site, in their community, and in their home. The EAP meets the Pollution Prevention Awareness Program requirements of DOE Order 5400.1 (DOE 1988a). The objectives of the EAP are as follows:

(1) Measurably raise the consciousness of the Westinghouse Hanford employees to the extent that they perform their jobs in a manner that prevents pollution and minimizes waste

(2) Provide a medium of communication to keep employees informed concerning cleanup and compliance activities; thus better equipping them to address the issues

(3) Encourage environmental awareness in the community

(4) Make Westinghouse Hanford a model of corporate environmental awareness and responsibility. 
The Pollution Prevention Awareness Program consists of four elements:

(1) pollution prevention awareness campaign, (2) awards and recognition,

(3) information exchange, and (4) training.

\section{B. POLLUTION PREVENTION ANARENESS CAMPAIGN}

The EAP has an Environmental Awareness Council that was developed for DOE Field Office, Richland by Westinghouse Hanford to promote environmental awareness among DOE Field Office, Richland and contractor employees, and within the community. Each contractor is represented on the council.

The Environmental Awareness Council will make extensive use of Site newsletters, seminars, bulletin boards, signs, and slogans to enhance employee awareness of and participation in pollution prevention at the Site.

The annual "Team Hanford" campaign promotes environmental excellence through pollution prevention awareness at the Hanford Site. Awards are given during the campaign to Site personnel who participate in minimization activities.

\section{AWARDS AND RECOGNITION}

The Waste Minimization and Reduction organization will recognize an individual or group's pollution prevention achievements on a quarterly basis.

\section{INFORMATION EXCHANGE}

An important element of the waste minimization program is the exchange of technical ideas. Activities to accomplish this are discussed in Section XII.

\section{E. TRAINING}

Another important element of the waste minimization program is training. The training program will include all levels of personnel at the Site. The goal of the training program will be to make each employee aware of waste generation, its impact on the Site and the environment, and ways waste can be reduced and pollution prevented.

Specialized Training Program. Training on the regulatory and company requirements with respect to waste minimization has been included in the Hazardous Waste Shipment Certification class (2006S), and Generator Hazard Safety Training (2006G). A segment also has been added to the Hanford General Employee Training, which provides annual training to all employees.

Procedures Qualification. As part of quality assurance, certain employees are required to be trained and examined on their knowledge of Site operating procedures before performing work. Waste minimization will be incorporated into operating, administrative, and waste procedures requiring 
documentation using data sheets or forms. Training on waste minimization, therefore, also will be conducted as part of the quality assurance procedures qualification process.

Performance Evaluations. Haste minimization goals, objectives, and accomplishments shall be incorporated into annual job performance evaluations of persons having waste minimization responsibilities.

\section{$X$. TRACKING AND REPORTING SYSTEME}

\section{A. TRACKING FROM POINT OF GENERATION TO POINT OF DISPOSITION}

A tracking system will be developed to identify waste minimization opportunities and provide essential feedback to successfully guide future efforts. The system will identify program resource requirements and report cost benefits realized from implementation of waste minimization projects. The data collected by the system will be used for internal reporting and to meet external reporting requirements discussed in Paragraph $D$ (Section $X$ ).

The system will track waste from point of generation to point of final disposition ("cradle to grave"). The system also will permit the tracking of hazardous materials from the point of entry to final disposition to comply with environmental regulations and reporting requirements. The system will collect data on input material, material usage, type of waste, volume, hazardous constituents, generating svstem, generation date, waste management costs, and other relevant information. A method also will be developed to trace materials that are being recycled or reclaimed and volumes of wastes eliminated because of waste minimization efforts. Existing tracking systems may be modified to meet this requirement if it is appropriate.

\section{B. PROCUREMENT CONTROL SYSTEM}

Procedures for control and purchase of hazardous chemicals or other materials will be reviewed to determine whether improvements in those procedures will aid in the achievement of waste minimization goals. The tracking system described in Paragraph $A$ (Section $X$ ) may be used to track the purchase and use of hazardous materials.

\section{PROGRAM ACTIVITY TRACKING}

A system to provide feedback on the progress of the waste minimization program, including the results of waste minimization technologies and other implemented waste minimization options, will be developed. 


\section{FEDERAL AND STATE REPORTING REQUIREMENTS}

Tracking systems develofed under this program will be designed to facilitate reporting waste millimization data and accomplishments to the DOE, $E P A$, and Ecology.

\section{QUALITY ASSURANCE}

Waste minimization activities shall retain an appropriate level of documentation and accountability to ensure an adequate level of confidence that the requirements of the DOE orders requiring reduction of waste are being met. Westinghouse Hanford has a Quality Assurance Program that addresses methods to ensure quality work. Quality Assurance will audit the Westinghouse Hanford waste minimization program and the individual facility-specific waste minimization programs to ensure verification of data reported in waste minimization reports.

\section{INFORMATION EXCHANGE AND OUTREACH}

All program staff are encouraged to make regular use of the EPA Pollution Prevention Information Exchange System and the DOE Waste Information Network database systems. The Westinghouse Hanford Waste Minimization organization representatives will attend the semi-annual DOE workshop on waste reduction and other forums or conferences when possible. Also, frequent onsite meetings to promote information exchange will be held.

\section{TECHNOLOGY TRANSFER}

The transfer of federally developed technology between laboratories and potential users is a contractual responsibility of DOE facilities and laboratories. Activities involving technology transfer will be coordinated through the office or committee within the facility that has been designated to represent the facility on the Federal Laboratory Consortium for Technology Transfer. The Federal Laboratory Consortium promotes technology transfer through links to the public and private sectors and through support services such as training and assistance in implementing partnership opportunities (e.g., cooperative agreements and patent licensing). Opportunities for transfer of technologies specific to waste minimization programs may develop from information exchange systems, workshops, or topical conferences. Direct exchanges of process technology between facilities are encouraged, but the support services of the Federal Laboratory Consortium should be used where appropriate. Technology projects that are identified and implemented should be coordinated with the U.S. Department of Energy-Headquarters (DOE-HQ), Office of Technology Development. 


\section{RESEARCH AND DEVELOPMENT}

Proposals for research and development (R\&D) are expected to arise from the waste assessment process described in Section VII. Some options may require development work before implementation. The assessments also may identify process inefficiencies that offer the potential for significant waste reduction, but specific process modifications may require R\&D work before implementation can be scheduled. Budget requests should include support for appropriate R\&D. Specific proposals for R\&D work will be coordinated through DOE Field Office, Richl and and the DOE-HQ, Office of Technology Development to ensure effective allocation of resources.

\section{PROgRaM EVALUATION}

The Waste Minimization Program will be evaluated semi-annually. All major activities will be reviewed. The evaluation will document program achievements and identify potential areas for improvement. Achievements and milestones in the program will be a part of the contractors' performance evaluation and determination of award fees.

ihe following success criteria are available to aid in the demonstration of effective waste minimization efforts:

- Reduced amount of hazardous waste

- Reduced amount of all waste

- Reduced waste maragement costs

- Improved regulatory compliance

- Reduced health risks

- Increased production efficiency

- Reduced accident risk

- Improved public relations.

A semi-annual report will be written to DOE Field Office, Richland. The report will contain current-year data, performance trends, forecasts, and measures used to gauge the performance of waste minimization activities. The evaluation report will be used to establish future waste minimization goals and program objectives. The report also will be used to determine changes to this plan. 


\section{REFERENCES}

DOE, 1988a, General Environmental Protection Program, DOE Order 5400.1, U.S. Department of Energy, Washington, D.C.

DOE, 1988b, Radioactive Waste Management, DOE Order 582v.2A, U.S. Department of Energy, Washington, D.C.

DOE, 1989, Hazardous and Radioactive Mixed Waste Program, DOE Order 5400.3, U.S. Department of Energy, Washington, D.C.

DOE, 1991, Hanford Site Waste Minimization and Pollution Prevention Awareness Program Plan, U.S. Department of Energy - Richland Field Office, Richl and Washington.

Ecology, 1991a, Dangerous Waste Regulations, Washington Administrative Code 173-303, Washington State Department of Ecology, Olympia, Washington.

Ecology, 1991b, Hazardous Waste Facilities Plans, Washington Administrative Code 173-307, Washington State Department of Ecology, 01ympia, Washington.

Ecology, EPA, and DOE 1990, Hanford Federal Facility Agreement and Consent Order, Washington State Department of Ecology, U.S. Environmental Protection Agency, and U.S. Department of Energy, 0lympia, Washington.

EPA, 1989b, Waste Minimization Opportunity Assessment Manual, EPA/625/7-88/003, U.S. Environmental Protection Agency, Washington, D.C.

EPA, 1990, EPA Guides to Pollution Prevention-Research and Educational Institutions, EPA/625/7-90/010, U.S. Environmental Protection Agency, Washington, D.C.

Omnibus Reconciliation Act of 1990, Section 6601, "Pollution Prevention Act of 1990," U.S. Environmental Protection Agency, Washington, D.C.

Resource Conservation and Recovery Act of 1976, as amended, 42 USC 6901 et seq.

Superfund Amendments and Reauthorization Act of 1986, Title III, Section 313, "Emergency Planning and Community Right-to-Know Act," Public Law 99-499, 100 Stat. 1613,42 USC 11001 et seq.

WHC, 1987a, "Waste Minimization," MP 5.17, Management Policy, CM 1-1, Westinghouse Hanford Company, Richland, Washington.

WHC, 1987b, "Waste Minimization Program," MRP 5.44, Management Requirements and Procedures, CM 1-3, Westinghouse Hanford Company, Richland, Washington. 
WHC-EP-0496

\section{APPENDIX A}

WASTE MINIMIZATION GOALS

\begin{tabular}{|l|c|c|c|c|c|c|}
\hline \multirow{2}{*}{$\begin{array}{c}\text { Waste } \\
\text { category }\end{array}$} & Baseline & \multicolumn{5}{|c|}{ Waste minimization goals } \\
(\% Mass)
\end{tabular}

- Goals may be reevaluated after completing process waste assessments on the individual streams that compose the waste category. Baseline values will be established from best available data for each waste stream.

b Values represent a percent reduction of the baseline value adjusted for changes in production rates, new processes, and site stabilization and remediation actions. 
WHC-EP-0496

This page intentionally left blank.

APP A-2 
Detailed Schedule for Waste Minimization Program Activities. (sheet 2 of 2)

\begin{tabular}{|c|c|c|c|}
\hline & Elements & Responsibility & Schedule \\
\hline \multicolumn{4}{|c|}{ PROGRAM EVALUATION } \\
\hline 1. & $\begin{array}{l}\text { Complete Program Evaluation } \\
\text { (all elements of this } \\
\text { evaluation contained in } \\
\text { semiannual report to DOE. } \\
\text { See "Reporting" below.) }\end{array}$ & WM\&R & June/December \\
\hline \multicolumn{4}{|c|}{ REPORTING } \\
\hline 1. & $\begin{array}{l}\text { Compile report data } \\
\text { Submit semiannual report } \\
\text { to DOE }\end{array}$ & $\begin{array}{l}\text { facility reps/ } \\
\text { WM\&R } \\
\text { WM\&R }\end{array}$ & $\begin{array}{l}\text { As necessary } \\
\text { June/December }\end{array}$ \\
\hline & $\begin{array}{l}\text { Submit biennial report to } \\
\text { Ecology }\end{array}$ & $\begin{array}{l}\text { WM\&R/DOE Field } \\
\text { Office, Richland }\end{array}$ & March ' $92, ' 94$ \\
\hline 4. & $\begin{array}{l}\text { Submit annual report } \\
\text { to DOE-HQ }\end{array}$ & $\begin{array}{l}\text { WM\&R/DOE Field } \\
\text { Office, Richl and }\end{array}$ & $\begin{array}{l}\text { March '92, '93, } \\
\text { '94 }\end{array}$ \\
\hline \multicolumn{4}{|c|}{ WASTE STREAMS GOALS } \\
\hline & $\begin{array}{l}\text { Establish company goals for } \\
\text { high-priority wastes } \\
\text { (hazardous, radioactive, } \\
\text { mixed) }\end{array}$ & WMER & $06 / 91$ \\
\hline & $\begin{array}{l}\text { Establish facility goals } \\
\text { for high-priority wastes }\end{array}$ & $\begin{array}{l}\text { facility reps/ } \\
\text { facility mgrs }\end{array}$ & $1 / 92$ \\
\hline & $\begin{array}{l}\text { Establish company goals for } \\
\text { lower priority wastes } \\
\text { (industrial and other) }\end{array}$ & WM\&R & $9 / 92$ \\
\hline & $\begin{array}{l}\text { Establish facility goals } \\
\text { for lower priority wastes }\end{array}$ & WM\&R & $1 / 93$ \\
\hline & $\begin{array}{l}\text { Compare trends to } \\
\text { established goals }\end{array}$ & WM\&R & Annually \\
\hline
\end{tabular}


WHC-EP-0496

\section{APPENDIX B}

\section{DETAILED SCHEDULE FOR WASTE MINIMIZATION} PROGRAM ACTIVITIES

Detailed Schedule for Waste Minimization Program Activities. (sheet 1 of 2)

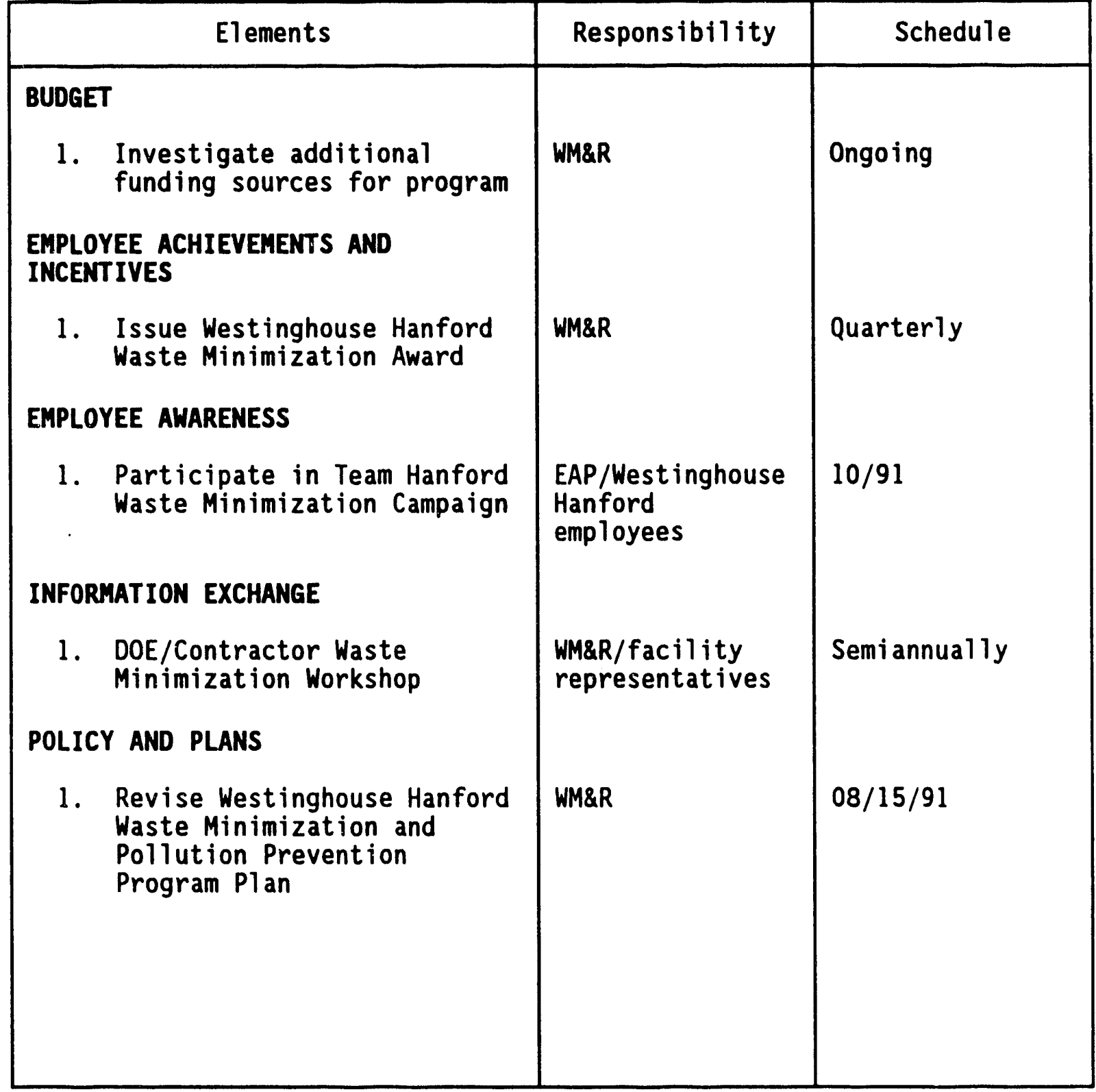


WHC-EP-0496

\section{DISTRIBUTION}

\section{Number of copies}

\section{ONSITE}

2

U.S. Department of Energy Field office, Richland

E. A. Bracken

A5-19

T. P. Pietrok

A5-19

2

Hanford Environmental Health Foundation

C. H. St. John

H1-52

L. J. Maas

B2-75

2

Kaiser Engineers Hanford

Company

W. H. Bodily

E3-33

K. A. DuPont

E3-33

2

Pacific Northwest Laboratory

W. J. Bjorklund

P7-68

E. P. J. Hauth

P7-68

West inghouse Hanford Company

J. G. Adler

S6-19

K. F. Armatis

R4-02

R. L. Baker

S4-08

D. L. Ball

R. E. Barker

L8-10

D. L. Barron

T5-53

S2-62

B. B. Bentley

G. R. Board

L8-10

W. R. Brooksher

S4-01

D. W. Brotherton

L4-01

L. C. Brown

T4-10

R. W. Brown

H4-51

K. L. Chubb

L6-79

J. E. Cottrell

L8-10

T7-20

P. A. Craig

D. L. Crockford

$\mathrm{H} 4-21$

N. R. Dahl

S. E. Dieterle

B. P. Dole

$\mathrm{H} 4-17$

N2-04

J. A. Eacker

D. B. Encke

L6-53

A2-50

R1-51

J. L. Epstein

R2-77

R4-01 


\section{DISTRIBUTION (cont)}

Number of copies

ONSITE

Westinghouse Hanford Company (cont)

75

D. J. Farquhar

B1-24

D. A. Faulk

T5-54

D. L. Fischer

Al-05

J. H. Garbrick

S4-08

D. E. Good

SO-97

E. F. Gray

J. M. Grover

R2-88

M. L. Grygiel

L5-55

P. R. Gunter

S6-65

W. H. Hamilton Jr.

SO-46

D. G. Hamrick

J. A. Harris

D. R. Herman

N3-10

RI-51

R. L. Hibbard

T6-14

T. M. Hohl

S4-01

T2-08

J. J. Holmes

S4-25

G. G. Hopkins

L5-55

J. A. King

N3-06

B. D. Kirk

S2-62

E. J. Kosiancic

$\mathrm{X} 1-82$

P. E. Lemargie

SO-61

D. W. Lindsey

C. D. Lucas

D. M. Lucoff

C. E. Marple

B1-24

$\mathrm{H} 4-21$

$\times 0-35$

$\mathrm{N} 1-35$

L6-55

W. J. Metz

J. C. Midgett

T2-08

J. A. Morrison

S6-15

R. D. Mudd

S5-10

G. L. Neer

T7-20

D. H. Nichols

L6-13

A. R. 01 ander

H4-21

F. J. Orsag

R1-51

A. F. Pardini

S2-62

K. A. Peterson

L6-36

A. D. Poor

S6-70

R. W. Powell

G4-10

R. D. Redekopp

L5-60

R. A. Riggers

$\mathrm{N} 1-38$

L. E. Russell

$\mathrm{N} 1-58$

L. B. Schiefelbein

N3-06

F. D. Schlien

J. A. Seamans

T1-06

R2-80

J. D. Thomson

$\mathrm{N} 1-36$

F. R. Turner

$\mathrm{R} 1-30$

G. E. Vansickle

$X 1-81$

M. J. Vitulli

$\mathrm{R} 2-81$

$\times 8-29$ 
WHC-EP-0496

\section{DISTRIBUTION (cont)}

Number of copies

ONSITE

75
Westinghouse Hanford Company (cont)

V. R. Weil

G4-04

M. T. Yoakum

Central Files

Document Clearance Administration

Document Processing and Distribution (2)
L7-97

L8-04

H4-17

L8-15

Distr-3 

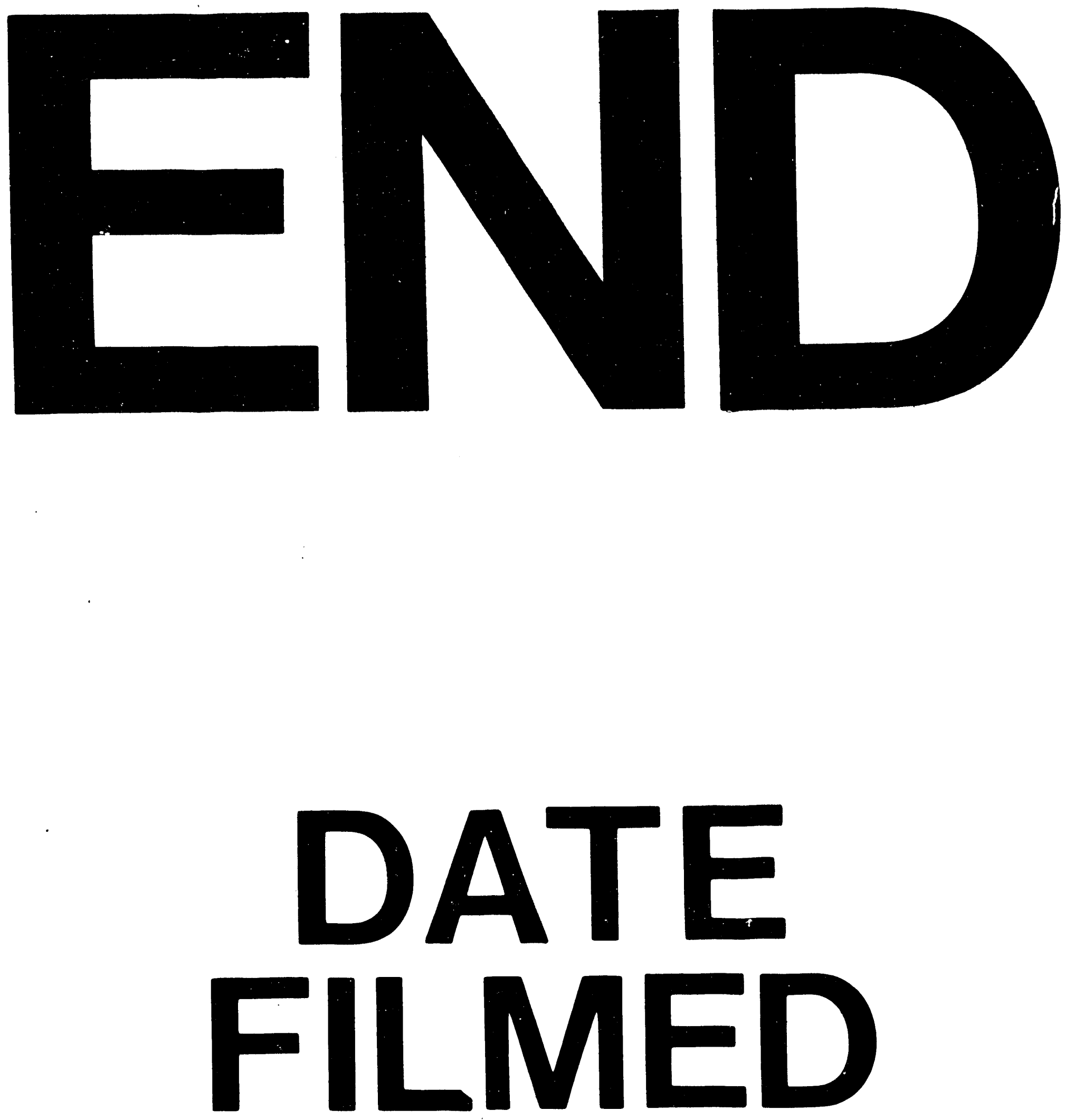

1

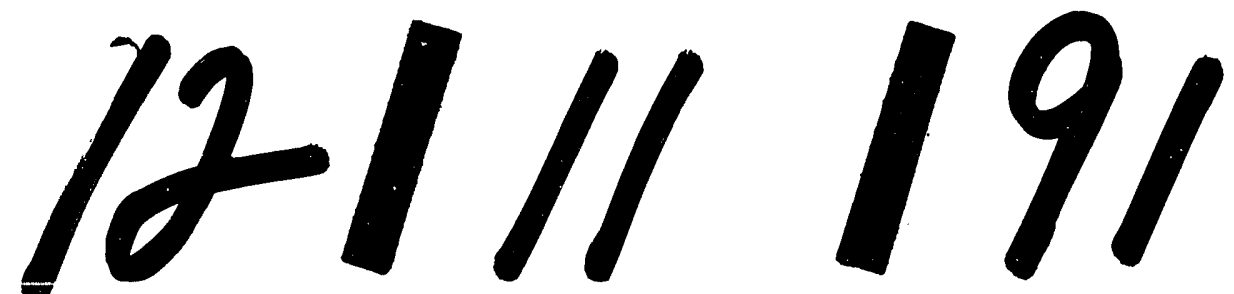

$I$ 
